\title{
How to Develop the EU Justice Scoreboard into a Rule of Law Index: Using an Existing Tool in the EU Rule of Law Crisis in a More Efficient Way
}

\author{
András Jakab ${ }^{1, \star}$ and Lando Kirchmair ${ }^{2}$ \\ ${ }^{1}$ University of Salzburg, Salzburg, Austria and ${ }^{2}$ Bundeswehr University Munich, Munich, Germany \\ ${ }^{\star}$ Corresponding author: andras.jakab@sbg.ac.at
}

(Received 02 July 2020; accepted 16 November 2020)

\begin{abstract}
In this Article we argue that rule of law indices are a powerful tool to detect ills in the rule of law of EU Member States. In order to explain how to improve the indices' potential, we give a critical overview of the methodological issues of the four rule of law indices which we consider particularly instructive for our purpose. These are the indices provided by the Freedom House ("Freedom in the World," FIW), the Bertelsmann Stiftung ("Bertelsmann Transformation Index," BTI), the World Bank ("Worldwide Governance Indicators," WGI), and the World Justice Project ("Rule of Law Index," WJP RLI). After analyzing the strengths and weaknesses of these indices, we turn to the EU Justice Scoreboard (EUJS). While the introduction of the EUJS in 2013 has already been an important step in order to lay the ground for an EU-wide analysis, in this Article we suggest how the EUJS should be further developed into a proper rule of law index by aggregating expert opinions into a single number. This would make the EUJS a significantly more useful tool in the ongoing EU rule of law crisis.
\end{abstract}

Keywords: EU rule of law crisis; rule of law indices; EU Justice Scoreboard; empirical legal research; Article 2 TEU values

\section{A. The EU Rule of Law Crisis and the Need for Working Rule of Law Indices}

In the past few years, the rule of law has been declining in many countries of the world, ${ }^{1}$ including several Member States of the European Union. ${ }^{2}$ The fear that more stable democracies could take such a turn is pervasive in public debate and scholarly discourse. ${ }^{3}$ The study of legal rules,

András Jakab is a constitutional lawyer with empirical training. He is based in Salzburg, formerly he held different research and teaching positions in Madrid, Budapest, Liverpool, Nottingham and Heidelberg. He is specialized in comparative constitutional law and EU constitutional theory.

Lando Kirchmair focuses as a lawyer on international, European, and national public law as well as legal philosophy. He is based in Munich and Salzburg and is interested in the interplay between the international, EU and member state legal orders as well as law and interdisciplinarity.

${ }^{1}$ Constitutional Democracy in Crisis? (Mark A. Graber, Sanford Levinson, \& Mark Tushnet eds., 2018).

${ }^{2}$ The Enforcement of EU Law and Values: Ensuring Member States' Compliance (András Jakab \& Dimitry Kochenov eds., 2017); C.H. Beck, Hard, \& Nomos, Constitutional Crisis in the European Constitutional Area (Von Bogdandy, Armin, \& Pál Sonnevend eds., 2015); Martin Brusis, Illiberale Drift Und Proliferation, BTIRegionalbericht OSTMitTel- Und SÜdosteuropa (2018).

${ }^{3}$ Edward Luce, The Retreat of Western Liberalism (2017); Yascha Mounk, The People vs. Democracy. Why Our Freedom is in Danger and How to Save It (2018); Aziz Huq \& Tom Ginsburg, How to Lose a Constitutional Democracy, 65 UCLA L. Rev. 78 (2018); Klaus Ferdinand Gärditz \& Maximilian Steinbeis, Die meisten Dinge, die in Polen und Ungarn gelaufen sind, könnten ohne weiteres hier auch passieren, VERFASSUNGSBLOG (Feb. 22, 2018), https://verfassungsblog.de/die-

(C) The Author(s) 2021. Published by Cambridge University Press on behalf of the German Law Journal. This is an Open Access article, distributed under the terms of the Creative Commons Attribution licence (http://creativecommons.org/licenses/by/4.0/), which permits unrestricted re-use, distribution, and reproduction in any medium, provided the original work is properly cited. 
nevertheless, yields only partial insight into the state of the rule of law. In particular, in cases of erosion of the rule of law, the main problem is the slow demise of the normativity of constitutional law, that is, the growing chasm between the constitution and constitutional reality. ${ }^{4}$ Amendments to formal legal acts say little about what and how things will change. If we do not want to remain blind to erosion, besides considering the formal rules, we must also examine the de facto conduct of addressees of these rules and the narrative accompanying it. The latter includes the social mentality or the political rhetoric regarding constitutional institutions. ${ }^{5}$ Fine-tuned constitutional law doctrine is always capable of identifying a de facto breach of the general requirements of the rule of law by the addressees of constitutional rules. However, the question regarding the gravity of such breaches cannot be captured with the standard tools of legal doctrine alone. In order to fully grasp reality, one should also resort to rule of law indices. ${ }^{6}$ Unfortunately, the existing rule of law indices, as we will see later in this Article, are not particularly helpful for the EU's current needs for different reasons.

While we are not in a position to offer a miraculous solution to the EU rule of law crisis in this Article, we wish to point to an important and so far largely overlooked element to diagnose rule of law defects. In this Article we argue that rule of law indices, if well designed, ${ }^{7}$ can be a powerful tool to detect ills in the rule of law of Member States. The introduction of the EU Justice Scoreboard (EUJS) in 2013 has already been an important step in order to lay the ground for an EU-wide analysis. It was primarily designed to address "the negative growth spiral" after the 2008 economic and financial crisis. ${ }^{8}$ For this reason, the EUJS is currently too concerned with the financial guarantees and the infrastructure of the judicial system, instead of a holistic analysis of the rule of law. Since 2020, however, the EUJS also informs the Annual Rule of Law Report to be presented by the European Commission. ${ }^{9}$ In this Article, we suggest how the EUJS should be further developed into a proper rule of law index because this would make the EUJS a considerably more useful tool in the EU rule of law crisis. The EUJS could not only play an important role in providing reliable data for political debates, but it could also inform the "Regulation on a general regime of conditionality for the protection of the Union budget"-which links the protection of

meisten-dinge-die-in-polen-und-ungarn-gelaufen-sind-koennten-ohne-weiteres-hier-auch-passieren/; Dalibor Rohac, Czech Republic and Slovakia Flirt with Authoritarianism, Financial Times (Mar. 27, 2018), https://www.ft.com/content/ 1f325970-2b84-11e8-a34a-7e7563b0b0f4; STEVe Levitsky \& Daniel Ziblatt, How Democracies Die (2018); Yascha Mounk \& Roberto Stefan Foa, The End of the Democratic Century. Autocracy's Global Ascendance, 97 FOREIGN AFFAIRS 29 (2018).

${ }^{4}$ András Jakab, What Can Constitutional Law Do Against the Erosion of Democracy and the Rule of Law? On the Interconnectedness of the Protection of Democracy and the Rule of Law, 6 CONSTITUTIONAL STUDIES 5, 5-34 (2020). See also Kristin Y. Albrecht, Lando Kirchmair, \& Valerie Schwarzer, Introduction, to DIE KRISE DES DEMOKRATISCHEN RECHTSSTAATS IM 21 JAHRHUNDERT 11-20 (Kristin Y. Albrecht, Lando Kirchmair, \& Valerie Schwarzer eds., 2020).

${ }^{5}$ For such an analysis see András Jakab, What is Wrong with the Hungarian Legal System and How to Fix it, MPIL ReSEARCH PAPER No. 2018-13 (July 13, 2018), https://ssrn.com/abstract=3213378. On the point that "laws on paper, no matter how imposing their terms, will not guarantee the he will live in the 'masterpiece of civilization,"' see generally Strømmen Lile, Lost in Operationalisation: Developing Legally Relevant Indicators, Questions and Benchmarks, 21 THE INTERNATIONAL Journal of Human Rights 1378-1400 (2017) (quoting Martin Luther King).

${ }^{6}$ For a showcase of combining empirical research based on indices with doctrinal rule of law questions, see Tim Ginsburg \& Mila Versteeg, Constitutional Correlates of the Rule of Law, in CONSTITUTIONALISM AND THE RULE OF LAW BRIDGING IDEALISM AND REALISM 506-525 (Maurice Adams, Anne Meuwese, \& Ernst Hirsch Ballin eds., 2017).

${ }^{7} \mathrm{Cf}$. Kim Lane Scheppele, The Rule of Law and the Frankenstate: Why Governance Checklists Do Not Work, 26 GOVERNANCE 559 (2013) (arguing that separate indicators without considering the interaction effects amongst them might fail to portray the true monster Frankenstate). For a similar argument, criticizing the 'fallacy of decomposition' see Mark Tushnet, Authoritarian Constitutionalism, 100 CORNELL L. REv. 391, 409-10 (2015).

${ }^{8}$ See Communication from the Commission to the European Parliament, The Council, the European Central Bank, the European Economic and Social Committee and the Committee of the Regions, at 1, COM (2013) 160 final (Mar. 27, 2013), https://ec.europa.eu/info/sites/info/files/justice_scoreboard_2013_en.pdf.

${ }^{9}$ See Communication from the Commission to the European Parliament, The Council, The European Economic and Social Committee and the Committee of the Regions, COM (2020) 580 final (Sept. 30, 2020), https://ec.europa.eu/info/sites/info/files/ communication_2020_rule_of_law_report_en.pdf. 
the budget of the Union to the generalized deficiencies of the rule of law in the Member Statesadopted on 16 December $2020 .^{10}$

\section{B. Why Measure Legal Systems? The Use of Rule of Law Indices}

There is a large number of indices that all measure legal systems. ${ }^{11}$ This can be explained by four factors. First, one single number can easily sum up complicated questions, ${ }^{12}$ so that nonprofessionals and the press can also use it. ${ }^{13}$ We should not underestimate this explanatory character, because this simplification can also contribute to democratic accountability. Second, indices are often also considered as external measures in debates about evaluating reforms or the performance of the government. ${ }^{14}$ Because of this, international organizations and NGOs use indices in order to foster and propagate best practices by comparing numbers of different countries. Exemplary countries usually score at the top of the scale set up by these organizations. ${ }^{15} \mathrm{~A}$ side-effect of this approach can be seen, for example, when a government solely changes a policy in order to change its score on a scale, without treating the real problem. ${ }^{16}$ Third, as already noted in our introductory part, rule of law indices can show the de facto situation - that is, law in action rather than law in books - they can also show the extent of improvements and deteriorations, and very importantly: These results cannot be discredited as "simply one opinion." Rule of law indices aggregate a large number of data including many expert opinions-if done well-in a transparent and controllable way. ${ }^{17}$ Fourth and finally, economists need quantitative data in order to test

\footnotetext{
${ }^{10}$ See Regulation 2020/2092 of the European Parliament and of the Council of 16 December 2020 on a General Regime of Conditionality for the Protection of the Union Budget, 2020 O.J. (L 4331), https://eur-lex.europa.eu/legal-content/EN/ALL/? uri $=$ CELEX\%3A32020R2092.

${ }^{11}$ Observing the increasing number of indicators and indices, in other words, the composite indicators, some authors speak about an "indicator fatigue." See generally Linn Hammergren, Indices, Indicators and Statistics: A View from the Project Side as to Their Utility and Pitfalls, 3 HAgUe J. Rule L. 311, 305-16 (2015).

${ }^{12}$ Michaela Saisana \& Andrea Saltelli, Rankings and Ratings: Instructions for Use, 3 Hague J. ON THE RULE OF L. 247, 24768 (2011).

${ }^{13}$ This is also dangerous because the measured value can also affect reality, for example, news about high levels of corruption can actually boost the acceptability of corruption itself, which can consequently also increase real corruption. See Tom Ginsburg, Pitfalls of Measuring the Rule of Law, 3 HAGue J. Rule L. 269, 270 (2011) ("Perceptions can produce their own reality."). $I d$. at 279 ("[A] bad image can become a self-fulfilling prophecy.").

${ }^{14}$ J. C. Botero, Robert L. Nelson, \& Christine Pratt, Indices and Indicators of Justice, Governance, and the Rule of Law: An Overview, 3 Hague J. ON THe Rule of L. 153, 159-60 (2011).

${ }^{15}$ For more about this problem in practice, and concerning the question of legitimacy, see Kevi E. Davis, Benedict Kingsbury, \& Engle Merry, Indicators as a Technology of Global Governance, 46 L. \& Soc'Y REV. 71-104 (2012); Armin von Bogdandy \& Matthias Goldmann, The Exercise of International Public Authority through National Policy Assessment: The OECD's PISA Policy as a Paradigm for a New International Standard Instrument, 5 INT'L ORGs. L. ReV. 241-98 (2008); Tor Krever, Quantifying Law: Legal Indicator Projects and the Reproduction of Neoliberal Common Sense, 34 THIRD World Q. 131-50 (2013); AnnJanette Rosga \& Margaret Satterthwaie, The Trust in Indicators: Measuring Human Rights, 27 Berkeley J. INT'L L. 253-315 (2009).

${ }^{16}$ Botero, Nelson, and Pratt, supra note 14, at 159. In general, see Andrea Saltelli, Composite Indicators between Analysis and Advocacy, 81 SOC. INDICATORS RES 65, 65-77 (2006).

${ }^{17}$ See, e.g., Sakiko Fukuda-Parr, Terra Lawson-Remer, \& Susan Randolph, Fulfilling Social and Economic RIGHTS 17 (2015) (Providing a measurement approach of social and economic rights and "find some surprising and counterintuitive relationships between rights fulfillment, on the one hand, and democratic governance, civil and political rights, social spending, economic growth, gender equality, and legal commitments, on the other."). On guidance of how to construct quantitative analysis in the field of human rights law, c.f., Lile, supra note 5; Christopher J. Fariss and Geoff Dancy, Measuring the Impact of Human Rights: Conceptual and Methodological Debates, 13 ANN. REV. L. Soc. SCIENCE 273, 273-294 (2017) (synthesizing theoretical approaches on human rights with theories of measurement, and differentiating a factualist, constructivist, and a constitutive approach). For a major database on all human rights recommendations that are outstanding against EU Member States, see also EU Fundamental Rights Information System, EU FRA, (July 15, 2021), https://fra.europa.eu/en/ databases/efris/. Cf. CIRI Human Rights Data ProjeCt, (July 15, 2021), http://www.humanrightsdata.com/p/data-

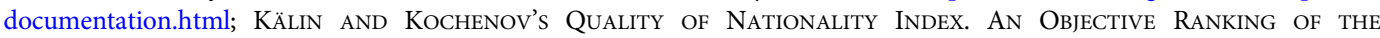
NATIONALITIES OF THE WORLD (Dimitry Kochenov \& Justin Lindeboom eds., 2020).
} 
political-economical correlations, for example between the rule of law and economic performance, therefore, the characteristics of legal systems need to be quantified. ${ }^{18}$

The challenge is that in all these cases we want to measure a phenomenon that is not directly observable, like the rule of law for example. ${ }^{19}$ Fortunately, statistics has several methods to handle this, and over the coming pages we will present this approach, without delving too deep into the mathematical details. We focus on the measurement of the rule of law, but the fundamental methodological problems are similar in the case of other indices measuring legal systems too. ${ }^{20}$

Quantification is not part of the traditional toolbox of a lawyer, ${ }^{21}$ and the attitude of lawyers toward statistical methods is also ambiguous, to say the least. ${ }^{22}$ On occasions they underestimate the indices because of the extent of simplification-or even discredit them, based on some unlikely outcomes-but at the same time they also admire the unintelligible mathematical models. In the present Article, we would like to find the golden mean between these two extreme approaches, by using the indices as important tools and as additional information for the better understanding of the overall view, while also treating them with precaution and critique.

A remark on terminology: By indicator we refer to a single number or feature, and by index we refer to composite indicators.

\section{Methodological Steps}

In this part we present the methodological questions based on the legal literature and on the OECD Handbook on Constructing Composite Indicators (2008). ${ }^{23}$ The main rule is that the design of the index must be transparent, and the methodological choices must be grounded, otherwise the indices are likely to serve pre-established policies. ${ }^{24}$

First, we must note that some steps of index-building presuppose a thorough knowledge of legal doctrine, for example, conceptualization, and other steps require expertise in working with quantitative data, for example handling and aggregating data. As there are very few experts who excel at both fields, index-building is usually carried out via team-based work, based on the cooperation of legal experts and data experts, even if they sometimes speak entirely different languages.

\footnotetext{
${ }^{18}$ Tero Erkkilä, B. Guy Peters \& Ossi Piironen, Politics of Comparative Quantification: The Case of Governance Metrics, $18 \mathrm{~J}$. Comp. Pol'y Analysis: Res. \& Prac. 319, 319-28 (2016).

${ }^{19}$ Daniel Kaufmann, Aart Kraay \& Massimo Mastruzzi, The Worldwide Governance Indicators: Methodology and Analytical Issues, 3 HAGUE J. Rule L. 220 (2011) (“inherently unobservable nature.”).

${ }^{20}$ E.g. Jos Blank, Martin Van der Ende, Bart Van Hulst \& Rob Jagtenberg, Bench Marking in an International Perspective: An International Comparison of the Mechanisms and Performance of the Judiciary System (2004).

${ }^{21}$ Indices can be useful in the field of comparative law too, see Ralf Michaels, Comparative Law by Numbers? Legal Origins Thesis, Doing Business Reports, and the Silence of Traditional Comparative Law, 57 AM. J. OF ComP. L. 765-796 (2009). But lawyers are usually cautious towards this approach. Other legal academics, linked to an underscoring system, used to emphasize the methodological shortcomings of the indices, e.g., Bénédicte Fauvarque-Cosson \& Anne-Julie Kerhuel, Is Law an Economic Contest? French Reactions to the Doing Business World Bank Reports and Economic Analysis of the Law, 57 AM. J. OF CoMP. L. 811, 811-30 (2009).

${ }^{22}$ See only the example given by Lile, supra note 5, at 1379 referring, for example, to research by Hans Otto Sano \& Halta Thelle, The Need for Evidence-Based Human Rights Research, in METHODS OF HuMAN RigHTS RESEARCH 96 (Foons Coomans, Fred Grünfeld, \& Menno T. Kamminga Eds., 2009) (pointing out that the papers published in the Human Rights Quarterly and the Netherlands Quarterly of Human Rights (between 2005 and 2007) do not use statistical analyses at all).

${ }^{23}$ OECD HandBook on CONSTRUCTING IndiCATORs 20-21 (2008), http://www.oecd.org/std/42495745.pdf.

${ }^{24} I$. See also René Urueña, Indicators and the Law A Case Study of the Rule of Law Index, in THE QUIET POWER OF Indicators: Measuring Governance, Corruption, and the Rule of Law 75, $96-97$ (Sally Engle Merry, Kevin E. Davis \& Benedict Kingsbury eds., 2015). Holding that "indicators, though, need to be generally perceived as nonpolitical by most of those who are being measured. Otherwise, they would lose most of their appeal." Yet Urueña also states that "it would be silly to attempt to" prevent the numbers produced by indices "from being used politically." To the contrary, "influence of an indicator derives from the fact that it is used by policymakers: otherwise, indicators would remain as a footnote in scholarly journals, with no influence in real life." However, while he suggests that indices "may be transformed into sites of contestation of the definition of what it means to adhere to the rule of law," we rather suggest that due to their political implications it is of utmost important to use transparent and rigorous methodology.
} 


\section{Conceptualization}

Before starting the construction of the index, we should clarify what we want to measure. ${ }^{25}$ Babbie, quoting Kaplan, places measurable things into three categories: 1) Direct observables like the number of seats in a parliament, 2) indirect observables, like the minutes of corporate board meetings which only convey indirect information on what actually happened, 3) and constructs or theoretical creations, such as IQ, or government performance. ${ }^{26}$ Lawyers have a special expertise in the latter field: one of the main parts of a lawyer's work relates to conceptual analysis. ${ }^{27}$ If we want to measure the rule of law, we have to define it.

The exact meaning of the rule of law as a term is, however, contested. ${ }^{28}$ It is mostly defined as a list of requirements or legal techniques that aim at inhibiting the arbitrary use of state power. ${ }^{29}$ Most characteristically, authors differentiate between formal-procedural (or thin) and materialsubstantive (or thick) requirements. ${ }^{30}$ Somewhat simplistically, the formal-procedural side includes such aspects as the stability of legal rules, compliance, and fair enforcement, whereas the material-substantive side includes foremost fundamental rights, as well as checks and balances. It is not possible and not necessary to enter into debates over the meaning of the rule of law here. ${ }^{31}$ Instead, taking into account the goal of our Article, we need to be aware of the structure of the concept as a list of requirements, and its anti-arbitrariness as a defining goal.

The various concrete definitions that are used by the various rule of law indices are usually based on legal-doctrinal opinions. If the majority of this legal-doctrinal professional community (constitutional lawyers of the relevant discourse, for instance) find the definition acceptable, for example, because it is based on authoritative legal documents, the definition seems to be appropriate. ${ }^{32}$ We can, of course, encounter numerous terminological debates ${ }^{33}$ about the concept of the rule of law, and because of the contested nature of values, we cannot expect a full consensus on this matter. ${ }^{34}$ The general advice, however, is that we should use a mainstream definition-when possible-with a small grain of caution. Because of the contested nature of the concept of the

\footnotetext{
${ }^{25}$ For our topic see, e.g., Jørgen Møller \& Svend-Erik SkaAning, The Rule of Law: Definitions, Measures, Patterns AND CAUSES 13-27 (2014).

${ }^{26}$ Earl R. Babbie, The Practice of Social Research 168-169 (13th ed., 2013); Abraham Kaplan, The Conduct of INQUiRY; Methodology FOR BeHAVIORAL SCIENCE 54-56 (2017).

${ }^{27}$ András Jakab, What Makes a Good Lawyer?, 62 ZEITSCHRIFT FÜR ÖFFENTLICHES RECHT 275-87 (2007).

${ }^{28}$ For the difficulty of clearly delineating the values enshrined in Article 2 TEU, see, e.g., Lando Kirchmair, Demokratische Legitimität, die EU-Rechtsstaatlichkeitskrise und Vorüberlegungen zu einer transnationalen Gewaltengliederung 6 (2) ZEITSCHRIFT FÜR PRAKTISCHE PHILOSOPHIE 171-212 (2019).

${ }^{29}$ For such an understanding the most recent rule of law report of the Commission, see COM (2020) 580 final, supra note 9 , at 1.

${ }^{30}$ C.f., e.g. HANDBOOK ON THE RULE OF LAW Ch. 1 (Christopher May \& Adam Winchester eds., 2018); Palombella, The Rule of Law as an Institutional Ideal, in RULE OF LAW AND DEMOCRACY: INQUIRIES INTO INTERNAL AND EXTERNAL ISSUES 4-37 (Leonardo Morlino \& Gianluigi Palombella eds., 2010); Randall Peerenboom, Human Rights and Rule of Law: What's the Relationship?, 36 (3) GEO. J. OF INT'L L. 809-945 (2005); Daniel B. Rodriguez, Matthew McCubbins, \& Barry Weingast, The Rule of Law Unplugged, 59 Emory L. J. 1455--94 (2009); Brian Z. TAMANaha, On the Rule of Law: History, Politics, TheORY (2004); Augusto Zimmermann, The Rule of Law as a Culture of Legality: Legal and Extra-Legal Elements for the Realization of the Rule of Law in Society, 14 Euro. LAW J. 10 (2007). For a good overview, see Alexandra Timmer, Concepts of Human Rights, Democracy, and the Rule of Law: A literature review, EUROPEAN Commission, http://www.fp7-frame.eu/frame-reps-3-1/2013.

${ }^{31}$ On these conceptual debates see, e.g., ANDrÁs JAKab, European Constitutional LANGUage (2016); Jørgen MølLER \& Svend-Erik SkaAning, Requisites of Democracy. Conceptualization, Measurement, and Explanation (2011). For various causal relationships, see Roberto Rigobon \& Dani Rodrik, Rule of Law, Democracy, Openness. And Income: Estimating Interrelationships (Nat'l Bureau of Econ. Research, Working Paper No. 10750, 2004) www.nber.org/papers/w10750.pdf.

${ }^{32}$ Saisana \& Saltelli, supra note 12 , at 249.

${ }^{33} \mathrm{On}$ this phenomenon in general, there is a lack of consensus and problems of definition in the case of composite indicators, see for example, Lovell Cherchye, Wim Moesen, \& Tom Van Puyenbroeck, One Market, One Number? A Composite Indicator Assessment of EU Internal Market Dynamics, 51 Eur. ECON. Rev. 749, 749-79 (2007).

${ }^{34}$ Botero, Nelson \& Pratt, supra note 14, at 166 (quoting Saisana \& Saltelli, supra note 12, at 248: "composite indicators are value laden constructs."). On the necessary political content of indices, see also Urueña, supra note 24, at 543-84.
} 
rule of law, the difficult task of finding a "common" opinion among experts can be shortcut by reference to official documents, for example, by the EU, the UN, the Council of Europe, or the European Commission.

Consequently, some indices diverge concerning the exact definition used, a problem that we will discuss later. Legal indices usually measure the de facto characteristics of a system, so a wellcrafted and substantively appealing law with a corrupt, oppressive, or ineffective implementation will underscore on these scales. ${ }^{35}$

\section{Selecting Data}

Once it is clear what shall be measured, the data for this measurement has to be found. The quality of a given legal system cannot be measured directly. Therefore, proxies (approximate data) have to be used: The opinion of experts or that of the public — soft data - or approximate facts—hard data -for example, the number of registered crimes, the budget of the courts, frequency of the modification of laws, frequency of the condemnation of a State by an international court of human rights. $^{36}$

The main concern about expert opinions is the choice of experts and the subjectivity of their opinions. This is an especially sensitive problem in politically polarized countries. ${ }^{37}$ As a partial remedy a transparent selection method is preferable. For instance, in a country with inter-ethnic tensions, the proportion of the experts should reflect the overall ethnic distribution. Alternatively, the use of as many experts as possible, by random sampling or with the participation of every available expert, is an appropriate way to address the challenge of selecting experts known as selection bias. ${ }^{38}$ A further problem is that in case of general questions, which is often characteristic of legal indices, it is not easy to find an expert who is up-to-date in every field. For example, criminal procedure, which is an important constituent of the rule of law, is usually not well known by constitutional lawyers. ${ }^{39}$ In several countries, participation brings risks for the expert too, if for example, he or she criticizes the current regime, even if anonymity is granted, obtaining unbiased reports will be more complicated. ${ }^{40}$ However, an obvious advantage of acquiring an expert opinion is that wide opinion polls are expensive, hard data are not always available from every single country, and some questions can only be answered by experts.

An important advantage of using opinion polls in the general population is that they also takes into consideration the situation of vulnerable groups. Even though opinion polls can also be biased, if they are professionally taken then the situation of these groups can be better represented than in expert opinions and in hard data. A further advantage of survey data is that it can also enlighten the differences between hard data and reality. ${ }^{41}$ Unfortunately, however, opinion surveys are expensive, and the questions are limited-as the general population cannot answer very specific questions. Sampling and measurement in no-go zones (in European countries it is less of a

\footnotetext{
${ }^{35}$ As a bad example, we can mention the RTI Rating, GLOBAL Right to INFORMATION Rating (July 15, 2021), http://www. rti-rating.org, in which two NGO's analyzed the situation relating to the right to information, but with rather surprising results: Moldova outscored the United Kingdom, and Russia performed better than the United States. Despite any disclaimer-such as that the implementation might differ from the written rule-it is a clear example of how unelaborated goal-setting and conceptualization can make indices completely useless.

${ }^{36}$ Jim Parsons, Developing Clusters of Indicators: An Alternative Approach to Measuring the Provision of Justice, 3 HAGUE J. ON THE RULE OF L. 170, 175-76 (2011).

${ }^{37}$ The UN Rule of Law Indicators (2011) 1, http://www.un.org/en/peacekeeping/publications/un_rule_of_law_indicators. pdf, (last visited 15 July 2021). In politically polarized countries, the results of the polls may vary: A popular government can increase trust in independent institutions, like the courts, and vice versa.

${ }^{38}$ Gajduschek, Miben áll, és mérhetö-e a kormányzati teljesítmény? (What Is and How to Measure Government Performance?), 3 Politikatudományi Szemle 97, 110 (2014).

${ }^{39}$ On this problem, see The United Nations Rule of Law Indicators supra note 25, at 24.

${ }^{40}$ The United Nations Rule of Law Indicators supra note 25, at 28.

${ }^{41}$ Parsons, supra note 36 , at 177.
} 
problem) and among vulnerable groups is also complicated. Public opinion is also very fluid, especially if it is influenced by the news. ${ }^{42}$ A further critique is the limited possibility of cross-country comparison, due to divergent historical mentalities. ${ }^{43}$

Although the use of hard data is objective, the scope of measurement is very limited. A large proportion of our questions cannot be measured even by using proxy hard data. It can also occur that while something is measurable by hard data, there is no data from a given country. We must also be cautious when using available data for four reasons: 1) Sometimes they are corrupted by the authorities, for example, the police sometimes discourage the victims of small crimes where there is a limited probability of success, in order to ameliorate statistics. 2) Sometimes, the measured value has an impact on the question only in extreme cases, for example, the budget of courts on the rule of law. 3) And sometimes, it is not at all obvious whether a boost of an objective value has a positive or a negative effect on the phenomenon - the high efficacy of public prosecutors can be indicative of an authoritarian judiciary tradition, while low efficacy can be indicative of incompetent prosecutors. 4) Finally, the partial nature of the data, in other words, objective data is only available on certain special questions, not on all questions which can lead to arbitrary selection.

Some indices combine the different sources, making the results more robust, see for example, the WJP-Index below, and the data sources are also cross-checked, via a method known as triangulation.

\section{Statistical Analysis}

There are different types of data: yes or no (binary data: 1 or 0 ), points on a given scale ${ }^{44}$ (ordinal data, for instance, the experts of the Freedom House evaluate the questions on a scale ranging from 1 to 7), percentages (metric data, for example, trust in institutions in the Eurobarometer), etc. In order to put all the data in one final index, we have to normalize (homogenize) them. ${ }^{45}$ For cross-country comparison, we have to adjust the data according to the size of the given country. ${ }^{46}$

There are several statistical methods for dealing with missing data. We can simply delete the whole row of data, for instance if an expert only answers twenty-four out of twenty-five questions, we can delete all of his or her answers, or we can just leave out the unanswered question. The problems are that: 1) The missing data are usually non-random, for example, some experts are afraid of answering several questions - in this case, simply disregarding the missing answer can bias the result; 2) deleting data can also decrease the reliability of the result-that is an increasing standard error. ${ }^{47}$ Therefore, if the quantity of missing data is more than five percent, we can use imputation. ${ }^{48}$ If, for example, an expert answered only twenty-four out of twenty-five questions, we can deduce her or his twenty-fifth answer by imputing this answer based on the other answers given by the expert. Or we can use the mean of the answers of the other experts, eventually belonging to the same cluster, based on the similar answers. We can also use a variety of other, more complicated statistical methods, and while each of these methods has a different advantage and inconvenience, we can reduce the bias of the outcomes based on these methods.

\footnotetext{
${ }^{42}$ Parsons, supra note 36 , at 178.

${ }^{43}$ Parsons, supra note 36 , at 179 .

${ }^{44}$ See BABBIE, supra note 26, at 155-58, 180-84 (setting levels of measurement in itself can be problematic: do we use nominal, ordinal, interval, or ratio measure?).

${ }^{45}$ For example, transforming a $0-1$ scale into $0-100$ means that 1 will be 100 , a $0-4$ scale into $0-100$ means that the value of 1 will be 25,2 is equal to 50,3 is 75 , and 4 is 100 . Another possible method is the standardization that is the rescaling of variables in order to obtain a zero mean and a standard deviation of one.

${ }^{46}$ Saisana \& Saltelli, supra note 12, at 251.

${ }^{47}$ Saisana \& Saltelli, supra note 12 , at 252.

${ }^{48}$ See Roderick J. A. Little \& Donald B. Rubin, Statistical Analysis with Missing Data (2d. ed., 2002) (on filling in for missing values).
} 
We must separately examine the non-arbitrary selection of the indicators, on which the indices are based. ${ }^{49}$ Indices based on many but bad indicators - meaning indicators which are actually irrelevant for the concept to be measured - are called "indicator rich but information poor." ${ }^{50}$ We can test this issue by using multivariate analysis. We examine the relation between the indicators, and the effect of them on the final outcome, in other words on the value of the rule of law index. Besides, we always have to test the influence of the individual variables on the final outcome, in other words, examine the robustness. ${ }^{51}$

We must also deal with outliers, meaning, the observations distant from other observations. In many cases, these result from measurement errors. Here too, we can use several statistical methods to handle the problem: We can simply delete the values, use imputation techniques, or introduce a natural logarithm, for example, to increase the goodness of fit. Of course, there are some real outliers too. We have to take them into consideration.

Weighting is an important question too. On the one hand, we can sum up the data with the same weight, but some characteristics are more important than others, for instance, concerning the rule of law, it is more important that the police cannot shoot innocent civilians arbitrarily, than the duration of a legal procedure. ${ }^{52}$ On the other hand, it is not easy to find an objective method for weightingdue to a lack of knowledge, and consequently, due to a lack of consensus between experts. ${ }^{53}$ When testing indices without weight, using multivariate analysis, we are only able to change them by adding or deleting indicators. In the case of weighted indicators, we can change the weight too, without deleting the indicator. The underlying method of weighting must be clear and explicit too. ${ }^{54}$ In several cases, weighting can be implicit too: If for instance, we build in strongly correlated indicators into the index, this also results in the weighting of the given question.

In order to lower the influence of extreme values on the final index (considering the example above: in order to avoid overscoring legal systems where the police can kill innocent people, but where other institutions are working well), we can use a geometric mean instead of an arithmetic mean. This allows for greater comparability, that is the state with the arbitrary police but with a good performance on other scales will not perform better than a similar (slightly underperforming) state without such an extreme value. ${ }^{55}$ Instead of using means, we can also use factor analysis, but the description of this method is beyond the framework of the present study. ${ }^{56}$

We can also build sub-indices from indicators. This is useful because 1) it can diminish misunderstandings and biases, occurring in the case of using isolated indicators, and 2) we can measure the complex and multi-faceted characteristic of the institutional functions. ${ }^{57} \mathrm{We}$ can even build dimensions from sub-indices. These are on a higher level of abstraction than the indicators,

\footnotetext{
${ }^{49}$ For a detailed look into democracy-indices, see Thomas Müller \& Susane Pickel, Wie lässt sich Demokratie am besten messen? Zur Konzeptqualität von Demokratie-Indizes, 48 PolitisCHE VIERTELJAHRESSCHRIFT 511, 511-39 (2007). For an overview of various strategies on how to measure democracy, see Jaso Seawright, \& David Collier, Rival Strategies of Validation: Tools for Evaluating Measures of Democracy, 47 CoMP. PoL. STUD. 111, 111-38 (2013). On governance indexes see Rachel M. Gisselquist, Developing and evaluating governance indexes: 10 questions, 35 POL'y STUD. 513, 513-31 (2014).

${ }^{50}$ OECD HandBook ON CONSTRUCTING INDICATORS 25 (2008).

${ }^{51}$ The multivariate analysis mentioned earlier shows the inner correlation structure of the indicators. Analyzing robustness on the contrary shows the influence of the indicators and methodological choices—normalization, weighting — on the index.

${ }^{52}$ As an example of a weighted index of the rule of law, see, e.g., Benny YT Tai, Developing an Index of the Rule of Law: Sharing the Experience of Hong Kong, 2 AsIAN J. OF COMP. L. 1, 1-19 (2007).

${ }^{53}$ Saisana \& Saltelli, supra note 12, at 254 (writing on the subjective character of weighting). For another source skeptical toward weighting, see OHCHR, supra note 37, at 5. For the methods of weighting, see the OECD HANDBOOK ON CONSTRUCTING INDICATORs 31-33 (2008); Andrew Sharpe \& Brendon Andrews, An Assessment of Weighting Methodologies for Composite Indicators: The Case of the Index of Economic Well-Being, CSLS RES. REP., No. 2012-10 (Dec. 2012). An example of an index without weights is the Islamic Constitutions Index, see Dawood I. Ahmed and Moamen Gouda, Measuring Constitutional Islamization: The Islamic Constitutions Index, 38 HASTINGS INT'L \& CoMP. L. Rev. 1, 1-74 (2015).

${ }^{54}$ Saisana \& Saltelli, supra note 12 , at 255.

${ }^{55}$ Saisana \& Saltelli, supra note 12, at 256. Instead of taking the sum of the values and dividing it by the number of numbers (arithmetic average), we take the $\mathrm{n}^{\text {th }}$ root of the product of $\mathrm{n}$ numbers (geometric average).

${ }^{56}$ See Howard Rosenthal \& Erik Voeten, Measuring Legal Systems, 35 J. CoMP. ECON. 711, 711-28 (2007).

${ }^{57} \mathrm{OHCHR}$, supra note 37 , at 3 .
} 
but on a lower level compared to the final index-for example, in the case of the rule of law, the efficiency of the justice system, or that of the police. We also can statistically test the relation between the dimensions, ${ }^{58}$ also in order to measure the effect on the final index. Here we can use factor analysis as well or principal component analysis or Cronbach's alpha test. ${ }^{59}$ Thereafter, we can correct the list of indicators, or the weights and the classifications into sub-indices, so that they measure similar but not identical things, with an existent but not full correlation. While building up the final index, we have to allow for the possibility of decomposition too, so that we can deduce from it the basic data and indicators. ${ }^{60}$

\section{Presenting, Interpreting, and Comparing Results}

The results are better represented in charts, but textual information is also needed for their interpretation. We have to keep in mind that the numbers in themselves can only represent the correlation. ${ }^{61}$ In order to establish a causal relation on the basis of this, the content needs to be considered further.

Visualization of the results with graphs, for example, can be instructive, too. These can influence (or manipulate) the interpretation and understanding, too. ${ }^{62}$ The results of an analysis extended to multiple countries can be represented on a map, or the countries can be classified into clusters. If there are other indices on the same question, we should compare them with our index, and we should also explain the differences.

\section{International Indices on the Rule of Law}

Here, we present four internationally recognized indices on legal systems. ${ }^{63}$ These are the indices of the Freedom House ("Freedom in the World," FIW), the Bertelsmann Stiftung ("Bertelsmann Transformation Index", BTI), the World Bank ("Worldwide Governance Indicators," WGI), and the World Justice Project ("Rule of Law Index," WJP RLI). ${ }^{64}$ We have chosen these four indices because they are internationally the most well-known ones, and their critical analysis is also helpful for improving the EUJS. In order to give a clear-cut picture, we represent the similarities and differences in a chart. ${ }^{65}$ In

\footnotetext{
${ }^{58}$ Stefan Voigt, How to Measure the Rule of Law, 65 KYKLOS 262, 262-84 (2012).

${ }^{59}$ OECD HANDBOOK ON CONSTRUCTING INDICATORS 25-27, 63-82 (2008).

${ }^{60}$ OECD HANDBOOK ON CONSTRUCTING INDICATORS 16 (2008).

${ }^{61} \mathrm{~A}$ well-known example on the difference between strong correlation and causality: According to superstition, the presence of storks can boost fertility. This belief seems to be confirmed by the data: Childbirth is correlated with the number of storks in a given region. In fact, in urbanized regions, the hunting-ground of storks is very limited. Parallel to this, in urban, industrialized regions, the birth rate used to be lower than in rural regions. So there is no causality between the number of storks and number of newborn babies. BABBIE, supra note 26 , at 94, 442-49 \& 483-84.

${ }^{62}$ See, e.g., Alexandru C. Telea, Data Visualization: Principles and Practice (2d. ed. 2015); Steffen-Peter Ballstaedt, Visualisieren: Bilder in wissenschaftlichen TeXten (2012).

${ }^{63}$ For a historically informed extensive overview, see Peter F. Nardulli, Buddy Peyton \& Joseph Bajjalieh, Conceptualizing and Measuring Rule of Law Constructs, 1850-2010, 1 J. L. \& CTs. 139, 139-92 (2013).

${ }^{64}$ For the former three, a good overview is given by Thiery, Shering \& Muno, Wie misst man Recht? Möglichkeiten und Grenzen der Messung von Rechtsstaatlichkeit, Kongressbeiträge, in INTERDISZIPLINÄRE RECHTSFORSCHUNG: KONGRESSBEITRÄGE WIE WIRKT RECHT (Estermann ed., 2009). Concerning Freedom House, for an overview on the historical conditions of the Freedom in the World indicator, see Christopher Bradley, International Organizations and the Production of Indicators: The Case of Freedom House, in The Quiet Power of Indicators: MEASuring Governance, Corruption, AND THE RulE OF LAW 27, 27-74 (Merry, Davis, \& Kingsbury eds., 2015) (concluding that "Freedom House's production of its indicator has been motivated primarily by the benefits to reputation and institutional identity that have accrued to the organization as a result of its indicator's prominence and credibility.").

${ }^{65}$ The chart is based on the following literature. For the first three indices: Svend-Erik Skaaning, Measuring the Rule of Law, 63 Pol. Res. Q. 449, 449-60 (2010); Thiery, Shering \& Muno, supra note 64; Kaufmann, Kraay, \& Mastruzzi, supra note 19; and the websites of the indices. For WJP RLI: Jim Parsons, Monica Thornton, Hyo Eun April Bang, Ben Estep, Kaya Williams, \& Neil Weiner, Developing Indicators to Measure the Rule of Law: A Global Approach. A Report for the World Justice Project, Vera Institute of Justice (2008); Juan Carlos Botero \& Alejandro Ponce, Measuring the Rule of Law (2011); EU Justice Scoreboard, EC (July 15, 2021), http://ec.europa.eu/justice/effective-justice/scoreboard/index_en.htm.
} 
the four indices, we also present the measurement of the rule of law, in order to point out the differences in conceptualization.

\begin{tabular}{|c|c|c|c|c|}
\hline & FIW & BTI & WGI & WJP RLI \\
\hline $\begin{array}{l}\text { Goals } \\
\text { (Measured } \\
\text { values?) }\end{array}$ & $\begin{array}{l}\text { Global comparative evaluation of } \\
\text { political rights and civil } \\
\text { liberties. }\end{array}$ & $\begin{array}{l}\text { Evaluates and measures the steps of } \\
\text { developing and transition countries } \\
\text { (Entwicklungs- und } \\
\text { Transformationsländer) toward } \\
\text { democracy and market economy. }\end{array}$ & $\begin{array}{l}\text { Aggregate and individual gover- } \\
\text { nance indicators. }\end{array}$ & $\begin{array}{l}\text { Measurement of the de facto } \\
\text { rule of law, based on the peo- } \\
\text { ple's experience, not on the } \\
\text { legal rules. }\end{array}$ \\
\hline $\begin{array}{l}\text { For how } \\
\text { long, how } \\
\text { frequently, } \\
\text { and in how } \\
\text { many coun- } \\
\text { tries? }\end{array}$ & $\begin{array}{l}\text { Yearly since } 1972,195 \text { countries to- } \\
\text { day (+15 disputed or special terri- } \\
\text { tories). }\end{array}$ & $\begin{array}{l}\text { Since } 2006 \text { two-yearly (a pilot study in } \\
2003 \text { ) today } 129 \text { developing and tran- } \\
\text { sition countries. That is every non- } \\
\text { member country of the OECD in } 1989 \text {, } \\
\text { provided that the population is over } 2 \\
\text { million. }\end{array}$ & $\begin{array}{l}\text { Since } 1996 \text {, and yearly since } 2002 \text {, } \\
\text { on } 215 \text { economies at the present } \\
\text { time. }\end{array}$ & $\begin{array}{l}\text { Yearly since } 2011 \text { (in 2012/13, a } \\
\text { unified biannual report), in } 102 \\
\text { countries. }\end{array}$ \\
\hline $\begin{array}{l}\text { Conceptual- } \\
\text { ization }\end{array}$ & $\begin{array}{l}\text { Political rights: } \\
\text { (1) Electoral process, } \\
\text { (2) Political pluralism and partici- } \\
\text { pation, } \\
\text { (3) Functioning of Government. } \\
\text { Civil Liberties: } \\
\text { (1) Freedom of Expression and } \\
\text { Belief, } \\
\text { (2) Associational and } \\
\text { Organizational Rights, } \\
\text { (3) Rule of law: in common sense } \\
\text { with somehow arbitrary elements, } \\
\text { (4) Personal Autonomy and } \\
\text { Individual Rights. } \\
\text { There are four questions on the } \\
\text { rule of law: } \\
\text { (1) Is there an independent judi- } \\
\text { ciary? } \\
\text { (2) Does the rule of law prevail in } \\
\text { civil and criminal matters? Are } \\
\text { police under direct civilian control? } \\
\text { (3) Is there protection from political } \\
\text { terror, unjustified imprisonment, } \\
\text { exile, or torture, whether by groups } \\
\text { that support or oppose the system? } \\
\text { Is there freedom from war and } \\
\text { insurgencies? } \\
\text { (4) Do laws, policies, and practices } \\
\text { guarantee equal treatment of various } \\
\text { segments of the population? }\end{array}$ & $\begin{array}{l}\text { The final index (Status Index) is } \\
\text { composed of a democracy and } \\
\text { market economy part. } \\
\text { The Democracy Index is based on } \\
\text { an explicit and philoso- } \\
\text { phically elaborate democracy-con- } \\
\text { cept: } \\
\text { (1) Stateness, } \\
\text { (2) Political participation, } \\
\text { (3) Rule of law, } \\
\text { (4) Stability of democratic institu- } \\
\text { tions, } \\
\text { (5) Political and Social Integration. } \\
\text { The four constituents of the rule of } \\
\text { law are partially overlapping, } \\
\text { according to the traditional legal } \\
\text { doctrine: } \\
\text { (1) Separation of powers, } \\
\text { (2) Independent judiciary, } \\
\text { (3) Prosecution of office abuse, } \\
\text { (4) Civil rights. }\end{array}$ & $\begin{array}{l}\text { For the six dimensions of governance: } \\
\text { (1) Voice and Accountability, } \\
\text { (2) Political Stability and Absence of } \\
\text { Violence, } \\
\text { (3) Government Effectiveness, } \\
\text { (4) Regulatory Quality, } \\
\text { (5) Rule of law, } \\
\text { (6) Control of Corruption. } \\
\text { "Rule of law captures perceptions of } \\
\text { the extent to which agents have confi- } \\
\text { dence in and abide by the rules of } \\
\text { society, and in particular the quality of } \\
\text { contract enforcement, property rights, } \\
\text { the police, and the courts, as well as } \\
\text { the likelihood of crime and vio- } \\
\text { lence.", } \\
\text { Conceptualization is questionable, } \\
\text { it is based rather on formal than sub- } \\
\text { stantive criteria. } \\
\text { Measuring rule of law on the basis of } \\
23 \text { sources (including the partial indi- } \\
\text { ces - and not the main indices - of } \\
\text { BTI, FIW, and WJP.) } \\
\text { Using } 86 \text { data units (44 of them are } \\
\text { representative, } 42 \text { are not). } \\
\\
\text { "Representative indicators are indica- } \\
\text { tors that cover a set of countries in } \\
\text { which the distribution of governance } \\
\text { is likely to be similar to that in the } \\
\text { world as a whole. ... In contrast } \\
\text { non-representative indicators cover } \\
\text { either specific regions (for example } \\
\text { the BEEPS survey of transition econo- } \\
\text { mies or the LatinoBarometer survey of } \\
\text { Latin American countries), or particu- } \\
\text { lar income levels (for example the } \\
\text { World Bank CPIA ratings that cover } \\
\text { only developing countries).".70 }\end{array}$ & $\begin{array}{l}\text { Based mainly on UN-documents, } \\
\text { the definition of the rule of law is } \\
\text { a system relying on the following } \\
\text { four } \\
\text { principles: } \\
\text { "(1) The government and its offi- } \\
\text { cials and agents as well as individ- } \\
\text { uals and private entities are } \\
\text { accountable under the law. } \\
\text { (2) The laws are clear, publicized, } \\
\text { stable, and just; are applied evenly; } \\
\text { and protect fundamental rights, } \\
\text { including the security of persons } \\
\text { and property and certain core } \\
\text { human rights. } \\
\text { (3) The process by which the laws } \\
\text { are enacted, administered, and } \\
\text { enforced is accessible, fair, and } \\
\text { efficient. } \\
\text { (4) Justice is delivered timely by } \\
\text { competent, ethical, and } \\
\text { independent representatives and } \\
\text { neutrals who are of sufficient num- } \\
\text { ber, have adequate resources, and } \\
\text { reflect the makeup of the commun- } \\
\text { ities they serve.",69 } \\
\text { According to the principles above, } \\
\text { they measure } 9 \text { factors and } 47 \text { sub- } \\
\text { factors: } \\
\text { (1) Constraints on Government } \\
\text { Powers, } \\
\text { (2) Absence of Corruption, } \\
\text { (3) Open Government, } \\
\text { (4) Fundamental Rights, } \\
\text { (5) Order and Security, } \\
\text { (6) Regulatory Enforcement, } \\
\text { (7) Civil Justice, } \\
\text { (8) Criminal Justice, } \\
\text { (9) Informal Justice } \\
\text { (i.e. traditional, tribal, and religious } \\
\text { courts).71 }\end{array}$ \\
\hline
\end{tabular}

(Continued)

${ }^{66}$ According to Thiery, Shering \& Muno, supra note 64, at 154, the correlation between the FIW and the BTI is very high (0.938), but the WGI correlates with the FIW and the BTI only by 0.664 and 0.663 respectively, which may indicate that the WGI is measuring something different to the other two.

${ }^{67}$ https://datacatalog.worldbank.org/rule-law-estimate (last visited 15 July 2021).

${ }^{68}$ Especially, critically, Ginsburg, supra note 13, at 271.

${ }^{69}$ What is the Rule of Law?, WORLD JUSTICE PROJECT, (July 15, 2021), http://worldjusticeproject.org/what-rule-law.

${ }^{70}$ Kaufmann, Kraay \& Mastruzzi, supra note 19, at 243.

${ }^{71}$ They also collect data on the 9th factor (Informal Justice) but they do not take into consideration in the aggregate index and in the ranking. These systems are especially complicated, and it is not too easy to measure comparably the efficiency and fairness in these cases. Therefore, the aggregate index is made up of 8 factors and 44 sub-factors "only." 


\section{(Continued.)}

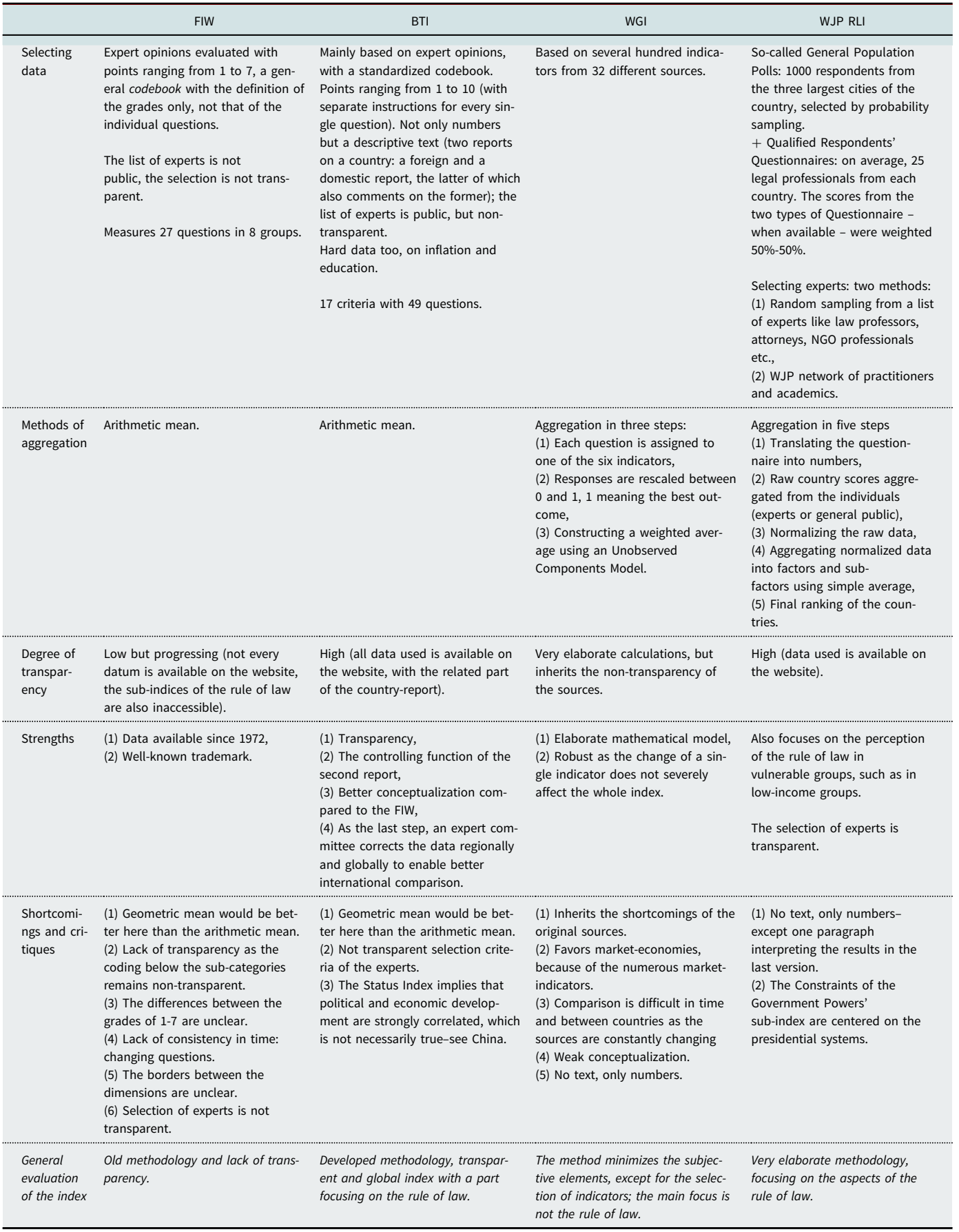


The Freedom House index-although it deserves praise for pioneering work, having been established already in 1972 and its almost universal coverage-is methodologically a dinosaur (unclear conceptualization, questions are partly overlapping, partly lack coverage; even the simple awareness of methodological problems seems to be missing). It also fundamentally lacks transparency, as, for instance, it is unclear who the experts are and how they are chosen.

The Bertelsmann Transformation Index, in contrast, features a sophisticated methodology. The transparent and global index also elaborates on democracy with a part focusing on the rule of law. However, for our purpose, the index is troublesome, as it does not include western European countries and thus, does not provide for an EU-wide standard which, however, is an indispensable prerequisite in order to measure the rule of law in all EU Member States with regard to Article 2 TEU in the EU. Using the BTI would bear the danger of double standards accusation, and rightly so. Nevertheless, the improvement of the EUJS could profit from the methodology of the BTI.

Similarly, the index of the World Justice Project is also a methodologically sophisticated project. Yet, the WJP index explicitly states that time series cannot be built based on it, as the questionnaire of the index is slightly changing year by year. This is a severe limitation. Nevertheless, if an index has the limitation of providing only static information-instead of displaying evolutionary developments-we can still compare the results of the various EU Member States, and we can also compare it to static benchmarks.

A virtue of the Worldwide Governance Indicators of the World Bank is that it minimizes the subjective elements, except for the selection of indicators, some of which, however, are only available for money. The main focus is, however, not on the rule of law, and the results stem from other indices and indicators, therefore the WGI necessarily inherits the methodological problems of the original indices and indicators that it aggregates. A further problem is that the countries are given a "percentile rank," which means that a country can easily "improve" in the ranking if many other countries deteriorate in the actual absolute quality of the rule of law values; or the other way around: It can place lower in the ranking if many other countries actually improve their quality of the rule of law.

\section{E. How to Develop the EUJS into an Index that can be Applied in the EU Rule of Law Crisis}

\section{The Unsuitability of Existing Indices for the EU Rule of Law Crisis}

The assessment of the existing indices above has shown that none of them are-albeit for different reasons - suitable for replacing the EUJS as they stand. While the Freedom House Index is outdated, the Bertelsman Index simply does not cover the EU Member States. The World Justice Project's methodology changes over time and therefore, does not allow an assessment of changes of the rule of law. The Worldwide Governance Indicators are not suitable either, as some Member States' results might look deceptively improving - without an actual improvement-due to the nature of the percentile rank of this index.

Finally, a generic legitimacy problem for the the EU with all mentioned indices is that they are done by external bodies. The EU should be able to set its own official standards, and not just rely on partly US-based NGOs. This NGO-objection does not apply to WGI. Before we can look into how to improve the EUJS, informed by the presented indices' strengths, we will look at the EUJS' current state of affairs.

\section{The EUJS as it Stands}

The EUJS is an initiative from the European Commission which was presented for the first time in March 2013. ${ }^{72}$ Since 2013, annual reports are published on the independence, quality, and

\footnotetext{
${ }^{72}$ See Press Conference and Speech by the EU Justice Commissioner Viviane Reding, The 2013 EU Justice Scoreboard, Brussels (March 27, 2013), https://ec.europa.eu/commission/presscorner/detail/fr/SPEECH_13_271.
} 
efficiency of justices systems of EU Member States. ${ }^{73}$ The 2020 EUJS "will also inform the Annual Rule of Law Report to be presented by the European Commission." ${ }^{74}$ It is, therefore, our proposal to further develop the EUJS into a rule of law index that should actually meet this new plan ${ }^{75}$ with a specific section devoted to judicial independence.

The data for the EUJS largely stems from the European Commission for the Efficiency of Justice (CEPEJ) of the Council of Europe (CoE) ${ }^{76}$ The CEPEJ was established in 2002 and uses some 170 qualitative and quantitative indicators on the efficiency and quality of justice. ${ }^{77}$ It is composed of 47 experts from all CoE Member States. ${ }^{78}$ Further, the data is received from national contact persons and a range of other sources. ${ }^{79}$

This plethora of sources is an issue of concern as various sources increase potential shortcomings, and a homogenous dataset cannot be guaranteed. ${ }^{80}$ Especially the heavy reliance on data from CEPEJ reports, which in turn bases its information on a questionnaire often answered by national correspondents within the ministries of justice, does not provide for objective data. ${ }^{81}$ Criticism extends to the informal "group of contact persons on national justice systems" which is an expert group of the Commission, established in 2013. ${ }^{82}$ Also, this group is comprised of officials of Member States, namely one person from the judiciary and one from the Ministry of Justice. Beyond that, this group must be criticized for a lack of transparency. ${ }^{83}$ Furthermore, the data gathered from the European Network of Councils for the Judiciary (ENCJ) depends on the basic functioning of the Member States' rule of law. The substitution of independent judges with party loyalists obviously infiltrates such national sources of data too. Finally, the lack of some data due to the reluctance of some Member States to provide the data is a serious shortcoming of the

\footnotetext{
${ }^{73}$ See Communication from the Commission to the European Parliament, The Council, the European Central Bank, the European Economic and Social Committee and the Committee of the Regions, COM (2013) 160 final (Mar. 27, 2013), https://ec.europa.eu/info/sites/info/files/justice_scoreboard_2013_en.pdf. For more information and all the Scoreboards since 2013, see EU Justice Scoreboard, EC (July 15, 2021), https://ec.europa.eu/info/policies/justice-and-fundamental-rights/ upholding-rule-law/eu-justice-scoreboard_en. For an analysis, see Adriani Dori, The EU Justice Scoreboard - Judicial Evaluation as a new Governance Tool (MPILux Working Paper 22015), http://www.mpi.lu/fileadmin/mpi/medien/ persons/Dori_Adriani/The_EU_Justice_Scoreboard_-_Judicial_Evaluation_as_a_New_Governance_Tool.pdf (speaking about a "remarkable unexpressed potential" of the EUJS "as a basis for experimenting with new governance tools in the area of EU Justice.").

${ }^{74} 2020$ EU Analysis of National Justice Systems, EC, (July 15, 2021), https://ec.europa.eu/info/law/better-regulation/haveyour-say/initiatives/7566555-2020-EU-Justice-Scoreboard.

${ }^{75}$ Communication from the Commission to the European Parliament, the Council, the European Central Bank, the European Economic and Social Committee and the Committee of the Regions, COM (2020) 306, https://ec.europa.eu/info/sites/info/files/ justice_scoreboard_2020_en.pdf (containing, in the foreword, an explicit statement from Didier Reynders, the European Commissioner for Justice, that, "[o]ver the next years of the Commission's mandate, we plan to develop the Score-board further, as well as all the instruments in our rule of law toolbox.").

${ }^{76}$ European Judicial Systems, Efficiency and Quality of Justice, CEPEJ STUDIES No. 26 CounCIL OF EUROPE (2018), https://rm.coe.int/rapport-avec-couv-18-09-2018-en/16808def9c.

${ }^{77}$ See The 2019 EU Justice Scoreboard, Communication from the Commission to the European Parliament, the Council, the European Central Bank, the European Economic and Social Committee and the Committee of the Regions, at 2, COM (2019) 198/2 (2019), https://ec.europa.eu/info/sites/default/files/justice_scoreboard_2019_en.pdf.

${ }^{78}$ Council of Europe European Commission for the Efficiency of Justice (CEPEJ), CounCIL OF Europe (July 15, 2021), https://www.coe.int/en/web/cepej/home/.

${ }^{79}$ See The 2019 EU Justice Scoreboard, supra note 77, at 2-3 (mentioning "the group of contact persons on national justice systems, the European Network of Councils for the Judiciary (ENCJ), the Network of the Presidents of the Supreme Judicial Courts of the EU (NPSJC), Association of the Councils of State and Supreme Administrative Jurisdictions of the EU (ACAEurope), the European Competition Network (ECN), the Communications Committee (COCOM), the European Observatory on infringements of intellectual property rights, the Expert Group on Money Laundering and Terrorist Financing (EGMLTF), Eurostat, the European Judicial Training Network (EJTN), and the World Economic Forum (WEF).") (citations omitted).

${ }^{80}$ See also critically Dori, supra note 73 , at 24.

${ }^{81} I d$. at $25-26$.

${ }^{82}$ See Framework for Commission Expert Groups: Horizontal Rules and Public Register, C(2010) 7649 final, SEC (2010) 1360 (Jan 10, 2010).

${ }^{83}$ Dori, supra note 73 , at 30 .
} 
EUJS, ${ }^{84}$ which is a consequence of the design choice to request the data from the Member Statesinstead of generating the data independently by using experts.

The EUJS originally had a very limited scope and was designed as a general information tool that enhances the effectiveness of Member States' justice systems. It is only since 2020 that the EUJS shall also provide information on the state of the rule of law in the EU Member States. ${ }^{85}$ This becomes crucial as current Commission President von der Leyen has also announced a new European rule of law mechanism which requires annual reports on the state of the Rule of Law across the EU. ${ }^{86}$ On September 30th 2020 the first Annual Rule of Law Report consisting of country specific qualitative analyses has been published by the European Commission. ${ }^{87}$ Indeed, the aim "to strengthen common values and the rule of law" 88 also featured very prominently as a top priority of the Finnish presidency. ${ }^{89}$ While the European Parliament has urged to establish an EU mechanism for democracy, the rule of law, and fundamental rights already, in June, 2015, ${ }^{90}$ it now seems that the European Commission understands the urgency of the situation and has initiated such a European mechanism. ${ }^{91}$ While this Rule of Law Report consists of a country-specific qualitative analysis of the major developments in Member States, according to Didier Reynders, current European Commissioner for Justice, it shall "benefit[... ] from the quantitative analysis of the Scoreboard where the reader can zoom in on national justice systems and information about their independence, quality and efficiency." ${ }^{\prime 2}$ In addition to previous editions of the EUJS, and "in response to the current need for more comparative information

\footnotetext{
${ }^{84}$ Dori, supra note 73 , at 32 .

${ }^{85}$ See in this regard only, Communication from the Commission, Further Strengthening the Rule of Law Within the Union, COM (2019) 163 final (April 3, 2019), https://eur-lex.europa.eu/legal-content/EN/TXT/HTML/?uri=CELEX:52019DC0163\& from=EN ("The European Semester, complemented by the EU Justice Scoreboard, has proven to be a good framework to develop country-knowledge relating to rule of law and a reflection could take place on whether their potential could be further exploited."). The European Parliament has lauded the Commission for this initiative and called to "take this exercise forward" already, early on in: Resolution on the EU Justice Scoreboard-Civil and Administrative Justice in the Member States, EUR. PAL. Doc. 2013/2117(INI), para. 1, (Feb. 4, 2014), https://op.europa.eu/en/publication-detail/-/publication/6086b5e0-1062-11e78a35-01aa75ed71a1. See also, COM (2020) 580 final, supra note 9, at 3.

${ }^{86} \mathrm{See}$ EUROPEAN COMMISsION, https://ec.europa.eu/commission/sites/beta-political/files/political-guidelines-nextcommission en.pdf, (last visited July 15, 2021).

${ }^{87}$ For an overview on the Abstracts, see Rule of Law 2020, Country Reports, EC (July 15, 2021), https://ec.europa.eu/info/ sites/default/files/rule_of_law_2020_country_reports_2_web.pdf. See also, Brzozowski, Belgium, Germany Make Joint Proposal for EU rule of Law Monitoring Mechanism, EuRACTIV (March 19, 2019), https://www.euractiv.com/section/ justice-home-affairs/news/belgium-germany-make-joint-proposal-for-eu-rule-of-law-monitoring-mechanism/on (Germany and Belgium had put forward a joint proposal for such an annual rule of law peer review in all EU member states).

${ }^{88} \mathrm{See}$, Finland's PREsidency OF THE COUNCIL OF THE EUROPEAN UnION, https://eu2019.fi/en/priorities/values-and-therule-of-law (last visited July 15, 2021).

${ }^{89}$ Despite the prominence of the topic, the takeover of the EU Council presidency by Slovenia has demonstrated the difficulty of addressing it. See, e.g., David Herszenhorn \& Hans von der Burchard, Rule of Law Disputes Cast Shadow over Opening of Slovenia's EU Council Presidency, POLITICO (Jul. 1, 2021, 9:31 pm), https://www.politico.eu/article/rule-of-law-disputeshadows-ceremonial-opening-of-slovenias-eu-council-presidency/.

${ }^{90}$ As for the EP, see EP Legislative Observatory, Establishment of an EU Mechanism on Democracy, the Rule of Law and Fundamental Rights, 2015/2254(INL); Resolution with Recommendations to the Commission on the Establishment of an EU Mechanism on Democracy, the Rule of Law and Fundamental Rights, Eur. PaL. Doc. 2015/2254(INL) (Oct. 25, 2016); Resolution on the Need for a Comprehensive Democracy, Rule of Law and Fundamental Rights Mechanism, EuR. PAL. Doc. 2018/2886(RSP) (Nov. 14, 2018).

${ }^{91}$ See Communication From The Commission To The European Parliament, The European Council, The Council, The European Economic And Social Committee And The Committee Of The Regions, Strengthening the Rule of Law Within the Union A blueprint for Action, COM (2019) 343 final (Jul. 17, 2019). See, however, for a critique of this Communication, Dimitry Kochenov, Elephants in the Room: The European Commission's 2019 Communication on the Rule of Law, 11 Hague J. Rule L. 423, 423-38 (2019).

${ }^{92}$ See Didier Reynders, European Commissioner for Justice, Foreword to The 2021 EU Justice Scoreboard, Communication from the Commission to the European Parliament, the Council, the European Central Bank, the European Economic and Social Committee and the Committee of the Regions COM(2021) 389 (2021), https://ec.europa.eu/info/sites/default/files/eu_justice_ scoreboard_2021.pdf.
} 
for the annual Rule of Law Report and for the monitoring of the National Recovery and Resilience Plans" the Commissioner states that "this year's edition goes further. There are new indicators on the digitalisation of justice systems, on the independence of national supreme court judges, on the autonomy of prosecution services and on the independence of lawyers and bars."

Despite this rather optimistic trend, there is still a pressing need to methodologically equip the EUJS in order to serve its important purpose. So far, the EUJS still is a rather limited tool focusing on so-called hard data without delving into a deep analysis of the context and background of the rule of law. It focuses on, for example, the "efficiency of justice systems" by looking at the caseload and estimated length of proceedings, or the assessment of the "quality of justice systems" by the criteria of accessibility to justice systems and adequate financial and human resources. ${ }^{94}$ This is problematic, as thereby, the EUJS misses what we described above as an essential element of the rule of law-the informal aspect of "law in action". Therefore, while we do not claim that all the criteria in the current EUJS are meaningless, it is nevertheless necessary that the EUJS extends its scope by actually measuring judicial independence and further important benchmarks of the rule of law. Instead of only highlighting basic features and figures of a justice system. ${ }^{95}$

The EUJS, as it stands, only measures whether a justice system is generally capable of delivering justice. It does not measure, however, whether it is actually working as an independent judiciary. Consequently, the outcome of the EUJS for a specific Member State might well be a high justice score, as the justice system is well equipped with staff and computers, despite actually not guaranteeing the rule of law due to arbitrary and biased results. Therefore, the EUJS cannot detect whether a Member State actually does not want to guarantee an independent rule of law. Or to put it directly, bad justice can be very effective. And while "the 2020 EU Justice Scoreboard shows updated indicators in relation to legal safeguards on the disciplinary proceedings regarding judges," 96 it is rather misleading to include figures on the "perceived independence of courts and judges among the general public"97_particularly when thinking of biased media-instead of referring to expert opinions. ${ }^{98}$ This verdict still holds true despite the improvements made in the EUJS 2021 referred to above by Commissioner Reynders. ${ }^{99}$

In addition, the focus of EUJS does not meet the broad understanding of the rule of law report published by the Commission. While the latter acknowledges the importance of informal rules for the rule of law, the former relies on formal rules:

The guarantees of structural independence require rules, particularly as regards the composition of the court and the appointment, length of service and grounds for abstention, rejection and dismissal of its members, in order to dispel any reasonable doubt in the minds of individuals as to the imperviousness of that court to external factors and its neutrality with respect to the interests before it. ${ }^{100}$

\footnotetext{
${ }^{93} I d$. at 92 .

${ }^{94}$ See The 2020 EU Justice Scoreboard, Communication from the Commission to the European Parliament, the Council, the European Central Bank, the European Economic and Social Committee and the Committee of the Regions COM(2020) 306, at 6. and 21., https://ec.europa.eu/info/sites/default/files/justice_scoreboard_2020_en.pdf, (last visited 15 July 2021); The 2021 EU Justice Scoreboard, (n. 92), at 7 and 21., https://ec.europa.eu/info/sites/default/files/eu_justice_scoreboard_2021.pdf, (last visited 15 July 2021).

${ }^{95}$ Thereby our proposal is more modest than the one by Petra Bárd, Sergio Carrera, Elspeth Guild \& Dimitry Kochenov, An EU Mechanism on Democracy, the Rule of Law, and Fundamental Rights: Assessing the Need and Possibilities for the Establishment of an EU Scoreboard on Democracy, the Rule of Law and Fundamental Rights, EUR. PARL. RESEARCH PAPER PE 579328, No. 2016-18, which aims at a much broader surveillance tool.

${ }^{96}$ The 2020 EU Justice Scoreboard, supra note 94, at 40.

${ }^{97}$ The 2020 EU Justice Scoreboard, supra note 94, at 41.

${ }^{98}$ This, however, becomes somewhat clear when comparing these results with the "perceived independence of courts and judges among companies." See The 2020 EU Justice Scoreboard, supra note 94, at 42.

${ }^{99}$ The 2021 EU Justice Scoreboard, supra note 92, at 41.

${ }^{100}$ The 2020 EU Justice Scoreboard, supra note 94, at 44. See also The 2021 EU Justice Scoreboard, supra note 92 , at 43.
} 
Surprisingly, the EUJS openly admits this shortcoming: “The figures presented in the Scoreboard do not provide an assessment or present quantitative data on the effectiveness of the safeguards. They are not intended to reflect the complexity and details of the safeguards. Having more safeguards does not, in itself, ensure the effectiveness of a justice system." ${ }^{101}$ Addressing this directly, we disagree with this self-imposed limitation. This actually unnecessarily limits the performance of the EUJS for its newly found purpose to inform the Commission and other EU organs on the actual state of affairs of Member States' justice systems concerning the rule of law. Rightly, the 2020 and the 2021 EUJS state that "[u]ltimately, the effective protection of judicial independence requires a culture of integrity and impartiality, shared by magistrates and respected by the wider society." 102 This can be depicted in a proper rule of law index. How this can be done, will be dealt with in the next section.

As the institutional shell of the EUJS already exists, it offers a chance of developing into something more useful in the current rule of law crisis: a rule of law index. ${ }^{103}$ In the current shape, the EUJS is, similarly to other actions taken by the EU in the rule of law crisis, more a Sisyphus-like exercise, instead of a serious and reliable tool to measure the rule of law. ${ }^{104}$ As another illustration of this rather harsh critique, we would like to point again to the 2019 EUJS which refers to " $[\mathrm{t}] \mathrm{he}$ importance for Member States to ensure the independence of national courts, as a matter of EU law." 105 However, instead of basing a lack of independence on the findings of the EUJS, the report has to refer to "the recent case law of the Court of Justice of the European Union." ${ }^{106}$ In this vein, the report points for instance to the fact that "the Court has clarified that the requirement of judicial independence also means that the disciplinary regime governing those who have the task of adjudicating in a dispute must display the necessary guarantees in order to prevent any risk of it being used as a system of political control of the content of judicial decisions." 107 The 2020 EUJS did not change that. While the 2021 EUJS "contains new indicators on authorities involved and status of candidates for the appointment of Supreme Court judges", ${ }^{108}$ these new figures do not display actual independence of judges. ${ }^{109}$ The EUJS still is not an adequate tool to address the rule of law crisis.

\footnotetext{
${ }^{101}$ The $2020 \mathrm{EU}$ Justice Scoreboard, supra note 94, at 44. See also The 2021 EU Justice Scoreboard, supra note 92 , at 43.

${ }^{102}$ The 2020 EU Justice Scoreboard, supra note 94 at 44; The 2021 EU Justice Scoreboard, supra note 92, at 43.

${ }^{103}$ With regards to democracy, the improvement of the EUJS could profit from the sophisticated V-Dem project, seen in VARIETIES of Democracy, https://www.v-dem.net/en/ (last visited Jul. 15, 2021).

${ }^{104}$ For a similar critique, see Israel Butler, How to Monitor the Rule of Law, Democracy and Fundamental Rights in the EU, Open Society European Policy Institute, 2 (Aug. 2013), https://www.opensocietyfoundations.org/uploads/aad3f011e848-4202-8c2b-2103219c31be/how-monitor-rule-law-democracy-and-fundamental-rights-eu.pdf (These criteria tell us very little about how effectively courts uphold the rule of law in terms of keeping governments' powers in check - a vital function for which the principal criteria would include judicial independence, how easily individuals can access the courts for judicial review, and the scope of the judiciary's authority to review and remedy violations by national authorities.").

See also Israel Butler, Enforce Respect for the Rule of Law?, VOICES, OpEN SOC'Y FOund. (Dec 13 2012) https://www. opensocietyfoundations.org/voices/justice-scoreboard-effective-mechanism-enforce-respect-rule-law (making the critique that "justice systems as a whole" should be monitored instead of a too narrow focus on civil and commercial courts).

${ }^{105}$ The 2019 EU Justice Scoreboard, supra note 77, at 8.

${ }^{106} \mathrm{Id}$.

${ }^{107}$ The 2019 EU Justice Scoreboard supra note 77, at 8 (referring to CJEU, C-216/18 PPU, ECLI:EU:C:2018:586, (July 25, 2018), para. 67). Similarly, the ongoing Article 7 TEU procedures and the rule of law framework are only mentioned in bypassing. Id. at 9. See also Alexander Strelkov, EU Justice Scoreboard: A New Policy Tool for 'Deepening' European Integration?, 27 J. CONTEMP. EUR. STUD. 15, 16 (2019) (stating that the EUJS is a "very technical instrument."). But see Id. at 18 ("Being a 'soft governance' tool, its added value lies in the provision of a systematic long-term annual overview by collecting information on aspects of national judicial systems, for example, caseload, length of court proceedings, anti-corruption measures and access to justice among disadvantaged groups. At the end, no single ranking is created but rather a comparative overview of how each national judicial system functions.").

${ }^{108}$ The 2021 EU Justice Scoreboard, supra note 92, at 43.

${ }^{109} \mathrm{Cf}$. for instance, The $2021 \mathrm{EU}$ Justice Scoreboard, supra note 92 , at 43 and the many references on recent case law of the CJEU.
} 


\section{The Steps Necessary to Improve the EUJS}

So what shall be done? How could we improve the EUJS? The best examples for our purposes are BTI and the WJP. We should therefore approximate the EUJS to those indices.

1. As we have seen, the main advantage of the rule of law indices is that they can aggregate a list of data into a single number-or a few numbers. So far, the EUJS cannot offer a single numerical value that would inform us about the rule of law in the Member States. Viviane Reding stated that the EUJS “is not a beauty contest. It's not about ranking national justice systems." ${ }^{110}$ Whereas it is true, that the main purpose is not to make a ranking, without a single number, the EUJS remains a half-hearted effort, and thus, merely a pretended action in the rule of law crisis. A ranking is just a side-effect of the overarching final numerical values - the index. It is nevertheless an essential tool. If the EUJS does not provide clearcut figures based on a sophisticated conceptualization, for instance, journalists will do sowithout a defendable concept. The most recent rule of law report from the Commission has been scanned for how often the terms "concern" and "serious concerns" appeared in each country's report on a specific Member State. This leads to a Member State ranking. ${ }^{111}$ It is of utmost necessity to clearly highlight if a Member State does not fulfill the requirements of the rule of law - and we also need to know by how much it falls short. All Member States have the obligation to guarantee Article 2 TEU values. The equality does not extend to severe shortcomings on which we must turn a blind eye just for the sake of keeping everyone happy. There is no way around this uncomfortable truth.

2. Independent expert opinions should be the primary data source for the EUJS. ${ }^{112}$ The obsession of EUJS with hard data, such as the length of proceeding, is a dead end. Qualities of a legal system cannot be measured based solely on hard data. It is not enough to only include surveys of the general public and companies on the independence of the judiciary-which is albeit not detrimental - in the EUJS either. In addition, especially in countries with the rule of law issues, it is also questionable whether the information, hard data, provided by the respective government is reliable. To improve the EUJS significantly, it would be important to include expert opinions, similarly as in the case of all rule of law indices-the WGI is using secondary data, some of which are based on expert opinions. As for the experts, their selection should focus on credentials that ensure independence: For example, scholarly achievements, if there are no doubts about the independence of the judiciary-higher judicial position, or alike.

3. Many questions that we are interested in cannot be answered based on hard data, for which the EUJS seems to have a very strong preference; maybe because it wants to look "objective." Rule of law indices are not "objective" in the sense that the results would emerge automatically from the data.

3.1 First of all, we need to clarify what we want to measure, and to do this, we must make certain conceptual choices. These conceptual choices have to be justified. The WJP and BTI both made sophisticated conceptual choices. They clearly lay out what they mean by the "rule of law." This groundwork is missing for the EUJS. You can either borrow the

\footnotetext{
${ }^{110}$ Reding, supra note 72.

${ }^{111}$ See David M. Herszenhorn \& Lili Bayer, European Commissioner for Justice Didier Reynders Gives a Press Conference on the Annual Rule of Law Report 2020, PoLITICO (Sept. 30, 2020), https://www.politico.eu/article/european-commission-reportfinds-many-eu-nations-hungary-poland-malta-bulgaria-falling-short-rule-of-law/.

${ }^{112}$ But see Mila Versteeg \& Tom Ginsburg, Measuring the Rule of Law: A Comparison of Indicators, 42 L. \& Soc. INQUIRY $100,100-137$ (2016), for the point that the four rule of law indices they have analyzed correlate significantly despite different methodology. While they suggest that expert opinions — and a too-small circle of experts_could because for this, it might also be the case that several ways lead to Rome.
} 
conceptual choices from the two named indices, or you can develop a new, probably very similar, one based on the treaties, especially Art 2 TEU, further EU documents such as the most recent 2020 Commission report on the rule of law, and case law of the CJEU. This is not particularly complicated-as the goal is not to come to terms with the one and only perfect solution, but a working concept. It is also doable in a couple of months with a number of experts and scholars. Even the Venice Commission, or the CEPEJ, can be involved, or their past documents can be used for this purpose. ${ }^{113}$

Therefore, the major shortcoming of the EUJS - in contrast to the most promising methodologically designed Bertelsmann Transformation Index-is the following: although the EUJS has been established in the wake of the already ongoing EU rule of law crisis, its current objective is not appropriate for providing valid data in order to make conclusions about the true quality of the rule of law in the EU Member States. The EUJS "focuses on litigious civil and commercial cases as well as administrative cases in order to assist Member States in their efforts to create a more investment, business and citizen-friendly environment." 114 This does not track what is actually problematic. To put it bluntly, instead of statistically displaying the availability of computers to national courts, it would be important to measure the independence of the judiciary, not in the perception of the general public or companies, but by the assessment of independent experts, ${ }^{115}$ or even more the quality of the rule of law writ large.

Consider this example: According to the 2019 EUJS, "the 2018 European Semester, based on a proposal from the Commission, the Council addressed country-specific recommendations to five Member States relating to their justice system."116 These five Member States did not include Hungary or Poland but rather included Croatia, Italy, Cyprus, Portugal, and Slovakia. ${ }^{117}$ This is noteworthy as the EUJS itself is meant to inform the European Semester. And indeed, this changed, as in "the 2020 European Semester, the Council, on Commission's proposal, addressed country-specific recommendations to eight Member States relating to their justice system," namely Croatia, Italy, Cyprus, Hungary, Malta, Poland, Portugal, and Slovakia. ${ }^{118}$

3.2 The method of aggregation should necessarily be based on certain choices, which need to be made on the basis of conceptualization. Sometimes there are several possible ways, but one must be chosen, and reasons must be given for the choice. Again, transparency is key.

3.3 The experts that will deliver the opinions should be numerous, and they should be selected in a transparent way. The selection method of WJP is that experts, who are unpaid, are selected on a random basis from very large lists, including all members of the bar, whereas

\footnotetext{
${ }^{113}$ The Rule of Law Checklist, Venice COMmission of THE Council OF EuR. (May 2016) https://www.venice.coe.int/ images/SITE\%20IMAGES/Publications/Rule_of_Law_Check_List.pdf.

${ }^{114}$ The 2019 EU Justice Scoreboard, supra note 77, at 2.

${ }^{115}$ The 2019 EU Justice Scoreboard supra note 77 at 47 includes for the first time, "indicators on bodies and authorities involved in disciplinary proceedings regarding judges [ . . ] , and, as last year [2018], shows an indicator on the appointment of judges-members of the Councils for the Judiciary". Yet, the caveat immediately following this message, is again disappointing:

"The figures presented in the Scoreboard do not provide an assessment or present quantitative data on the effectiveness of the safeguards. They are not intended to reflect the complexity and details of the safeguards. Having more safeguards does not, in itself, ensure the effectiveness of a justice system. It should also be noted that implementing policies and practices to promote integrity and prevent corruption within the judiciary is also essential to guarantee judicial independence. Ultimately, the effective protection of judicial independence requires a culture of integrity and impartiality, shared by magistrates and respected by the wider society."

${ }^{116}$ The 2019 EU Justice Scoreboard, supra note 77, at 6.

${ }^{117}$ However, rather ironically, Hungary and Poland are mentioned among those countries which have been financially supported in implementing "certain justice reforms through the European Structural and Investment Funds (ESI Funds). Since 2007, 16 Member States have used both the European Social Fund (ESF) and the European Regional Development Fund (ERDF) to improve the effectiveness of their justice systems." The 2019 EU Justice Scoreboard, supra note 77 at 7.

${ }^{118}$ The 2020 EU Justice Scoreboard supra note 96, at 5, n. 18.
} 
each selected expert should have the possibility of recommending new ones. The V-Dem Project, specialized on measuring democracy, has a country coordinator for every country who selects experts - who are offered a small amount of payment-based on predetermined criteria. There are different ways to make the selection of experts, but in any case, this needs to be done in a transparent way. You can also call these experts the "Copenhagen Commission" if you prefer. ${ }^{119}$

\section{F. By Way of Conclusion: Limitations and Perspectives of an Improved EUJS}

It is important to acknowledge that quantifiable findings in themselves cannot provide the basis for automatic action. ${ }^{120}$ Instead, the results need to help prudent doctrinal analysis by providing weights to violations of the rule of law requirements. An improved EUJS could also play a more central role in the political discourse, helping in agenda-setting and it could pressure recalcitrant Member States, and those politicians from other countries who try to defend the indefensible for reasons of party alliances. ${ }^{121}$ It could help to determine whether a "serious and persistent" breach of the rule of law exists according to Article 7(2) TEU and help courts in finding whether "general or systemic deficiencies" in the rule of law of a Member State are present. ${ }^{122}$

Reliable data can also inform the "Regulation on a general regime of conditionality for the protection of the Union budget" which has been adopted on 16 December $2020 .{ }^{123}$ For instance, the principle of a proportionate financial measure enshrined in the new EU rule of law mechanism could be informed by an improved EUJS drawing on rule of law indices. Thereby, the sensitive matter of determining the amount could be supported also by quantitative data. This is important, because the Commission will face high political pressure when acting under the new rule of law

\footnotetext{
${ }^{119}$ We borrow the expression from Müller, A Democracy Commission of One's Own, or What it would take for the EU to Safeguard Liberal Democracy in its Member States, in The Enforcement of EU LAW ANd VAlues: Ensuring Member StATES' Compliance 234-51 (András Jakab \& Dimitry Kochenov, eds., 2017). In Müller's proposal, the Copenhagen Commission, however, would deliver qualitative doctrinal analysis, similar to the Venice Commission.

${ }^{120}$ As opposed, for example, to constitutional deficit brakes or debt brakes. It is an open question even whether in these areas this automatism is appropriate or not. See András Jakab, Sustainability in European Constitutional Law, MPIL RESEARCH PAPER, No. 2016-16 21-27 (July 2, 2016), https://papers.ssrn.com/sol3/papers.cfm?abstract_id=2803304. In any case, we do not suggest any "legal automatism".

${ }^{121}$ See precisely for this argument-albeit with reference to a "democracy scoreboard"-Ulrich Sedelmeier, Political Safeguards Against Democratic Backsliding in the EU: The Limits of Material Sanctions and the Scope of Social Pressure, 24 J. OF EUR. PUb. PoL'Y 337, 337-51 (2017). For proposals to consider already existing indexes for decision-making (but including also a qualitative analysis each time), see Lauret Pech, Rule of Law as Guiding Principle of the European Union's External Action (Centre for Law of EU External Relations Working Paper 2012/3, 2012), http://www.asser.nl/ media/1632/cleer2012-3web.pdf; Laurent Pech, The EU as a Global Rule of Law Promoter, 14 AsIA EUR. J. 7, 7-24 (2016).

${ }^{122}$ See Case C-216/18 PPU, Minister for Justice and Equality v LM, ECLI:EU:C:2018:586 (July 2018), paras. 23 (which is also known as Celmer, due to the non-anonymized names of the relevant parties in the Irish proceeding Minister for Justice \& Equal. v. Celmer [2018] IEHC 119.). For a doctrinal analysis of "systemic deficiency" see the latest Armin von Bogdandy, Principles of a Systemic Deficiencies Doctrine: How to Protect Checks and Balances in the Member States, 57 CML REV. 705-40 (2020) (especially 715). For further similar doctrinal suggestions see, generally, Armin von Bogdandy \& Michael Ioannidis, Systemic Deficiency in the Rule of Law: What it is, What has Been Done, What can be Done, 51 CML REV. 5996 (2014), and referring to the gravity or the "systemic" nature of violations, which are, in our view, difficult to establish without quantitative measures, see Armin Von Bogdandy, Matthias Kottmann, Carlino Antpöhler, Johanna Dickschen, Simon Hentrei \& Maja Smrkolj, Reverse Solange- Protecting the Essence of Fundamental Rights against Member States, 49 CML Rev. 489-519 (2012); Iris Canor, My Brother's Keeper? Horizontal Solange: “An Ever Closer Distrust Among the peoples of Europe", 50 CML REV. 383 (2013).

${ }^{123}$ See Regulation 2020/2092 of the European Parliament and of the Council of 16 December 2020 (EU, Euratom), on a General Regime of Conditionality for the Protection of the Union Budget.
} 
mechanism. Having the possibility to rely on an improved EUJS which presents clear data on rule of law breaches in EU Member States based on independent expert opinions, would significantly strengthen the position of the Commission against charges of politically motivated action. ${ }^{124}$

Proper measurement of the rule of law at the EU level is necessary because arguably all current governments of EU Member States will claim that they actually follow the rule of law standards in their respective countries. This, however, is doubtable, to say the least. An EU-wide index can provide for very valuable and largely neutral, or at least with respect to the EU Member States, comparable data on such claims. In order for the EUJS to accomplish such a task, the above-suggested improvements are necessary.

\footnotetext{
${ }^{124}$ See already András Jakab and Lando Kirchmair, How to Quantify a Proportionate Financial Punishment in the New EU Rule of Law Mechanism?, VerfassungsBlog (Dec. 22, 2020), https://verfassungsblog.de/how-to-quantify-a-proportionatefinancial-punishment-in-the-new-eu-rule-of-law-mechanism/.

Cite this article: Jakab A, Kirchmair L (2021). How to Develop the EU Justice Scoreboard into a Rule of Law Index: Using an Existing Tool in the EU Rule of Law Crisis in a More Efficient Way. German Law Journal 22, 936-955. https://doi.org/10.1017/ glj.2021.46
} 